\begin{tabular}{|l|l|l|}
\hline \multicolumn{2}{|c|}{ PublisherInfo } \\
\hline \hline PublisherName & $:$ & BioMed Central \\
\hline \hline PublisherLocation & $:$ & London \\
\hline \hline PublisherImprintName & $:$ & BioMed Central \\
\hline \hline
\end{tabular}

\title{
H-chain CDR3 contribution in specificity of autoantibodies
}

\begin{tabular}{|l|l|l||}
\hline \multicolumn{2}{|c|}{ ArticleInfo } \\
\hline \hline ArticleID & $:$ & 119 \\
\hline \hline ArticleDOI & $:$ & $10.1186 /$ ar-2001-66875 \\
\hline \hline ArticleCitationID & $:$ & 66875 \\
\hline \hline ArticleSequenceNumber & $:$ & 76 \\
\hline \hline ArticleCategory & $:$ & Paper Report \\
\hline \hline ArticleFirstPage & $:$ & 1 \\
\hline \hline ArticleLastPage & $:$ & 3 \\
\hline \hline & & RegistrationDate : 2001-1-12 \\
\hline ArticleHistory & $:$ & OnlineDate \\
\hline \hline ArticleCopyright & $:$ & Biomed Central Ltd2001-12 \\
\hline \hline ArticleGrants & $:$ & \\
\hline \hline ArticleContext & $:$ & 130753311 \\
\hline \hline
\end{tabular}


Aff1 CNRS, Strasbourg, France

\section{Keywords}

\section{Context}

Systemic lupus erythematosus is characterized by the production of antibodies directed against various nuclear antigens. Many groups have focused on the sequence of the $\mathrm{V}$ region genes of antinuclear antibodies and several features accounting for DNA binding have emerged from these sequences, especially in VH-CDR (H3). In this study, the authors exchanged $\mathrm{H} 3$ domains between the 3H9 antibody and two donor antibodies, LG8-1 (closely related to 3H9) and ASWA1 (divergent from 3H9). The H3 domain of these three antibodies differed in the number of arginine residues and in overall charge and these antibodies share different specificities. Variant $\mathrm{H}$ chains were expressed together with the $3 \mathrm{H} 9$ light chain as single-chain Fv ( $\mathrm{scFv}$ ), and the five antibodies were then tested for their ability to bind nucleosomes, DNA and cardiolipin.

\section{Significant findings}

The five scFvs equally bind cardiolipin, suggesting that this recognition is not due to junctional or somatic diversity mechanisms. In contrast, the DNA and nucleosome binding activity was only observed for $3 \mathrm{H} 9 \mathrm{scFv}$ with its own H3. It is surprising that the exchange with LG8-1 H3, which is arginine-rich, is not sufficient to restore the ability of this antibody to bind DNA. These results suggest that conformation, flexibility or additional sidechain contributions of 3H9 H3 are crucial, and are directly involved in DNA and nucleosome binding.

\section{Comments}

This study demonstrates that binding of autoantibodies to DNA, nucleosomes or cardiolipin is due to more than attraction between opposite charges. Indeed, the authors show that the presence of arginine in $\mathrm{H} 3$ is not sufficient to explain binding to DNA. Another important point in this paper is the 
demonstration that binding to antigens that share common epitopes (DNA, nucleosomes and cardiolipin) does not require similar contributions from $\mathrm{H} 3$. The authors propose that the germline of the $3 \mathrm{H} 9 \mathrm{VH}$ domain is directly involved in cardiolipin binding, whereas structural features of $\mathrm{H} 3$ guide the maturation of antibody binding toward nuclear autoantigens such as DNA or nucleosomes. This paper highlights the contribution of somatic mutations to binding constraints imposed by $\mathrm{H} 3$. Because only five combinations were tested here, further studies will be needed to validate the model proposed by the authors. X-ray structures would help to delineate the fine 3D interactions between antigen and antibody.

\section{Methods}

scFv construction and expression, ELISA, DNA sequencing

\section{References}

1. Seal SN, Monestier M, Radic MZ: Diverse roles for the third complementarity determining region of the heavy chain (H3) in the binding of immunoglobulin Fv fragments to DNA, nucleosomes and cardiolipin. Eur J Immunol. 2001, 30: 3432-3440.

This PDF file was created after publication. 